REVISTA DE DERECHO UNED, NÚM. 14, 2014

\title{
EL TÍTULO CONSTITUTIVO DE LA DEUDA COMO TÍTULO EJECUTIVO EN EL PROCESO DE EJECUCIÓN HIPOTECARIA
}

\section{ESTABLISHING THE TITLE OF DEBT AS EXECUTIVE TITLE IN THE FORECLOSURE PROCESS}

\author{
Soraya Callejo Carrión \\ Prof. ${ }^{\text {a }}$ Dra. Derecho Procesal Centro Universitario Villanueva \\ Abogada
}

Resumen: En el presente artículo se aborda el estudio del título ejecutivo en el proceso de ejecución hipotecaria. Sin perjuicio de que a efectos prácticos la discusión no tiene relevancia, en el ámbito científico, por el contrario, pueden plantearse dudas acerca de cuál es verdaderamente ese título: el de crédito, es decir, aquel en el que se documenta la relación obligatoria (préstamo o crédito), o el título inscrito, aquél en que se hace constar la hipoteca. La propia LEC utiliza indistintamente las dos expresiones para referirse al título ejecutivo y, si bien, lo habitual es que consten en el mismo instrumento o escritura pública, cabe preguntarse si se documentaran por separado, cual sería en verdad el título. La autora considera que es el título de crédito.

Palabras claves: Proceso de ejecución hipotecaria. Título ejecutivo. Título de crédito. Título inscrito.

Abstract: In this paper the study of enforcement is addressed in the foreclosure process. Notwithstanding that for practical purposes the discussion is irrelevant, in science, in contrast, may be doubts about what is truly that title: the credit, ie, that in which mandatory relationship is documented (loan or credit), or the registered title, the one in which it is stated the mortgage. The LEC itself uses the two 
terms interchangeably to refer to the enforcement order and, although it will normally stated in the instrument or deed, one wonders if documented separately, which would indeed be the title. She believes that it is the credit title.

Key words: Foreclosure process. Title executive. Title credit. Title inscribed.

Recepción original: 10/02/2014

Aceptación original: 13/03/2014

Sumario: I. El título de crédito como título ejecutivo. II. La copia ejecutiva de la escritura pública. III. La integración del título ejecutivo: el supuesto de la hipoteca flotante. III.1. La ejecutabilidad de la hipoteca flotante por el proceso de ejecución hipotecaria. III.2. La necesaria integración del título. IV. El documento fehaciente como complemento de la certificación bancaria. V. Ejecuciones parciales: el ámbito de la hipoteca flotante. VI. El documento público electrónico. VII. La limitada ejecutoriedad de la escritura pública. VIII. La ejecución hipotecaria sin título ejecutivo. IX. Carácter ejecutivo del documento privado de mediación (acuerdo).

\section{EL TÍTULO DE CRÉDITO COMO TÍTULO EJECUTIVO}

La vigente LEC no aporta una definición de lo que se entiende por título ejecutivo, de la misma forma que tampoco lo hacía la anterior Ley Procesal de 1881. Se limita tan solo a enumerar los títulos que llevan aparejada ejecución en su art. 517, a diferencia de lo que acontece en el Reglamento Hipotecario, cuyo art. 33 define a efectos de inscripción el título ejecutivo en los siguientes términos: «se entenderá por título, a los efectos de la inscripción, el documento o documentos públicos en que funde inmediatamente su derecho la persona a cuyo favor haya de practicarse aquella y que hagan fe, en cuanto al contenido que sea objeto de la inscripción, por sí solo o con otros complementarios, o mediante formalidades cuyo cumplimiento se acredite». La doctrina española ha debatido sobre la naturaleza del título ejecutivo; esencialmente, pueden estructurarse en dos las posturas mantenidas al efecto. Mientras que para algunos autores, el título ejecutivo es un acto del que el documento seria únicamente el instrumento constitutivo, para otros, el título propiamente dicho es el documento, aunque éste refleje o sea instrumento de constitución de un acto jurídico. En cualquier caso, parece que la polémica hoy está superada, toda vez que los actos jurídicos en sí mismos considerados son insuficientes para entablar un proceso de ejecución, pues siempre 
ha de aportarse un instrumento de constancia, que ordinariamente es un documento.

En efecto, sostienen, DE LA OLIVA Y VEGAS TORRES que la polémica puede considerarse, de un lado, no certeramente planteada $\mathrm{y}$, por otro, superada. Dada su función los títulos ejecutivos son, sobre todo, determinados documentos, porque cabalmente al Derecho y a la Ley les interesa, como fundamento y clave del inicio del proceso de ejecución y de su desarrollo, la constancia suficientemente clara de lo jurídico en casos concretos. Pero no cabe excluir que algunos comportamientos, declaraciones o manifestaciones de voluntad, sean legalmente tomados en consideración para atribuirles por sí mismos o, en unión con documentos, fuerza ejecutiva, con tal de que se trate de comportamientos perfectamente comprobables y comprobados ${ }^{1}$.

El título constitutivo de la obligación es el fundamento de toda pretensión ejecutiva hipotecaria, la causa petendi de la pretensión.

Estipula el art. 685.2 de la LEC que «a la demanda se acompañaran el título o títulos de crédito, revestidos de los requisitos que esta Ley exige para el despacho de la ejecución, así como los demás documentos a que se refieren el artículo 550 y, en sus respectivos casos, los artículos 573 y 574 de la presente Ley». Por su parte, el art. $517^{2}$ del mismo texto legal afirma: «la acción ejecutiva deberá fundarse en un título que tenga aparejada ejecución», y cita, entre otros, y en lo que aquí interesa, a la escritura pública con tal que sea primera copia; o si es segunda, que esté dada en virtud de mandamiento judicial y con citación de la persona a quien deba perjudicar, o de su causante, o que se expida con la conformidad de todas las partes».

Atendiendo a la letra estricta de la Ley procesal, debe afirmarse que el fundamento de todo proceso de ejecución es siempre un título

${ }^{1}$ Derecho procesal....ob, cit, pág. 35 .

${ }^{2}$ De los términos en que se pronuncia este precepto no puede sostenerse que la enumeración que realiza sea una enumeración cerrada o a modo de numerus clausus, máxime después de la reforma introducida por la Ley 37/2011 de medidas de agilización procesal que al modificar el apartado 9..$^{\circ}$ del apartado 2 del art. 517 para introducir la referencia a resoluciones procesales, parece querer otorgar fuerza ejecutiva a ciertas resoluciones de los Secretarios judiciales. Cuestión que confirma el art. 518 cuando alude a la caducidad de la acción ejecutiva fundada en resolución del Secretario Judicial. Por otro lado, en sí mismo el apartado $9 .{ }^{\circ}$ no deja de ser una especie de cajón de sastre en el que se incluyen todas aquellas resoluciones procesales y documentos que por disposición de esta u otra ley lleven aparejada ejecución. En todo caso, lo que sí resulta indudable es que la atribución de la consideración de un documento, el que sea, como título ejecutivo, depende estrictamente de la ley. Es decir, lo que convierte a un documento en título ejecutivo es una disposición expresa de la Ley, al margen de cuál sea el fundamento por el que se atribuye tal consideración. 
ejecutivo (art. 517), y, en el caso concreto de la ejecución hipotecaria, (art. 685.2), dicho título no es otro que el título de crédito cuando está revestido de las condiciones exigidas para llevar aparejada ejecución, pues no todo título de crédito sin más es ejecutivo, ni abre el acceso a este proceso especial de ejecución.

En este contexto, resulta oportuno insistir en que el objeto de ejecución es el título ejecutivo, del que resulta la existencia de la deuda, no la hipoteca, cuya virtualidad radica, no tanto en suplantar el título que lleva aparejada ejecución, sino en privilegiar y asegurar su buen fin. Se ejecuta, por tanto, el título, no la hipoteca ${ }^{3}$.

La regla general según la cual el título ejecutivo es fundamento de toda ejecución no tiene ninguna excepción, tampoco en el proceso de ejecución hipotecaria. Tan sólo cabe subrayar en este punto una singularidad propia del título ejecutivo hipotecario cual es que está dotado de cobertura hipotecaria, de ahí que la demanda ejecutiva hipotecaria deba acreditar la conexión registral del crédito con la garantía.

Ello no obstante, existe cierta confusión conceptual derivada del hecho de que en la práctica uno y otra (crédito e hipoteca) se plasman en un mismo documento, la escritura pública. Pero, si se documentaran separadamente, hay que tener presente que el único título ejecutivo sería la escritura de préstamo (o crédito), no la escritura de hipoteca. La hipoteca no sirve ni como título material ni formal. Sostiene PAZ-ARES que de la misma manera que no se ejecuta un embargo, tampoco se ejecuta una hipoteca que es una suerte de traba anticipa$\mathrm{da}^{4}$. Lo anterior, es lo contrario a lo sostenido por MONTERO AROCA,

${ }^{3}$ Sostiene PAZ-ARES que dos ideas confluyen a la formación de la acción ejecutiva. Por una parte, el derecho material (crédito) que justifica la pretensión dineraria que se satisface por medio del procedimiento de ejecución, y por otra parte, el título formal en que se funda aquella. Ciertamente, desde una óptica procesal, el título formal adquiere mayor relevancia. Como dice el art. 517 LEC, «la acción ejecutiva deberá fundarse en un título que lleve aparejada ejecución». Es éste, y no tanto el derecho material lo que constituye la base inmediata de la ejecución. Se trata de una ejecución caratular, porque se presume la existencia del crédito reflejado en el documento ejecutivo. De ahí que en el momento de decidir sobre el despacho de la ejecución no se exija al juez que compruebe la existencia material del derecho del acreedor sino la regularidad formal del título ejecutivo y su congruencia con la ejecución solicitada. Hacia un nuevo Derecho Hipotecario. Estudios sobre la Ley 41/2007, de reforma del mercado hipotecario. Academia Sevillana del Notariado. Consejo General del Notariado. págs. 179 y 180 .

${ }^{4} \mathrm{Ob}$, cit, pág. 181. Igualmente, sostiene este autor «...siempre es preciso un título ejecutivo. Si se otorga una escritura entre A y B en virtud de la cual el primero hipoteca un inmueble a favor del segundo, en garantía de una supuesta cantidad que a éste le adeuda $\mathrm{C}$, ¿Acaso esa escritura de hipoteca es título suficiente para que B pueda proceder en vía ejecutiva hipotecaria (o en cualquier otra) contra C, e incluso contra 
quien considera que en la ejecución hipotecaria, en realidad, existen dos títulos ejecutivos, uno, la escritura pública en la que se documenta el derecho de crédito y, otro, la escritura pública en la que se constituye la hipoteca ${ }^{5}$. Pues bien, esto es precisamente lo que lleva a PAZARES a hablar de la denominada conexión hipotecaria, que explica en base a la exigencia del art. 685.2: que a la demanda ejecutiva se acompañe el título inscrito (el título con la nota de inscripción), o, en su defecto, el título y la certificación registral acreditativa del acceso tabular de la hipoteca y su subsistencia. Considera que el precepto distingue entre título y garantía (inscrita). Mientras que el título de crédito es insustituible, la conexión hipotecaria puede acreditarse de diversas formas. Y deja patente, a su juicio, que no se precisa que el título ejecutivo esté inscrito, ni por tanto, el acceso tabular del derecho material que incorpora. La inscripción como requisito de la ejecución hipotecaria constituye únicamente una exigencia de la hipoteca pero nunca del título de crédito. Por consiguiente, basta con que figure inscrita la hipoteca que le da cobertura en su estructura mínima de carga o derecho real, y, una vez acreditada la conexión entre el título de crédito y la hipoteca, procede el despacho de la ejecución.

No obstante lo anterior, esta postura defendida por PAZ-ARES y MIRA ROS ${ }^{6}$ no es pacífica, pues hay autores como MONTERO ARO$\mathrm{CA}$, ya citado, que concluyen que aun cuando la LEC habla de título de crédito, sin especial mención a la hipoteca, no cabe duda de que el título de la ejecución es la escritura pública de hipoteca debidamente inscrita en el Registro de la Propiedad, y no la que pueda documentar el crédito garantizado ${ }^{7}$. En sentido coincidente, JURADO sostiene que

A? Si A constituye una hipoteca en garantía de los daños que pueda originar a B como consecuencia de una determinada actividad, la escritura de hipoteca, ¿puede suplir el título judicial que determine la indemnización por daños? Evidentemente, los interrogantes planteados no pueden sino responderse negativamente. En ambos casos faltaría el título del que resulte el deber de entregar una cantidad de dinero a que se refiere el art. 571 LEC. La hipoteca, en cuanto estructura jurídico-real, es (o al menos, puede ser) muda en cuanto al contenido obligacional garantido». Ob, cit, pág. 182.

${ }^{5} \mathrm{Ob}$, cit, pág. 279.

${ }^{6}$ Esta autora se pronuncia en términos semejantes al sostener con base en el art. 685.2 LEC que no se ejecutan los bienes dados en garantía, sino la obligación garantizada; por tanto, afirma, el fundamento de la demanda o causa petendi de la pretensión ejecutiva es el título constitutivo de la deuda y no la inscripción registral de la hipoteca. La ejecución se despacha a la vista del título, siempre que se trate de alguno de los revestidos por la Ley de fuerza ejecutiva, como la escritura pública y los demás mencionados en el art. 517, entre los que no se incluye la inscripción, pues la deuda no es inscribible, ni la calificación registral se extiende a ella. Un enfoque procesal... ob, cit, pág. 12 .

${ }^{7} \mathrm{Ob}$, cit págs. 333-336. Este autor entiende que lo que ha llevado al legislador a hacer referencia tan solo al crédito y no a la hipoteca ha sido la tradición. Desde 
el título es la copia inscrita de la escritura de constitución de la hipoteca cuya ejecución se pretende ${ }^{8}$. HERBOSA, por su parte, igualmente en contra de lo que aquí se sostiene, considera que el título no es tanto la escritura en la que se documenta el crédito como aquella en la que se constituye la hipoteca, ya que el acto jurídico en el que se asienta la ejecución es el de constitución de la garantía9. MONSERRAT VALERO siguiendo la tendencia mayoritaria, considera que el título ejecutivo es la escritura de constitución de la hipoteca ${ }^{10}$.

Una postura ecléctica es la que mantiene DOMÍNGUEZ, cuando afirma la necesidad de acompañar también el título de crédito para la ejecución, si bien, MONSERRAT puntualiza que tal exigencia es meramente formal y no justificaría que la escritura de préstamo fuera también título para la ejecución hipotecaria ${ }^{11}$.

Por su parte, Martín DIZ, ${ }^{12}$ en un intento por explicar el fundamento de la duda sobre cuál es el verdadero título ejecutivo hipotecario, alude a lo que, desde su punto de vista, es un auténtico dislate jurídico, consistente en no diferenciar los dos actos contenidos en la escritura de constitución hipotecaria, integrada habitualmente por dos relaciones diferentes y complementarias, como son la relación crediticia, en forma y manera de préstamo, y la relación garantizadora de la anterior, la hipoteca. Al ser la escritura el documento público que, según el art. 517 LEC, lleva aparejada ejecución, la concesión del crédito cede en importancia frente a la segunda, la hipoteca, que sí debe constar en el Registro y, por tanto, se encuentra relacionada con la información publicitaria del Registro de la Propiedad.

siempre la escritura pública convertida en título ejecutivo es aquella de la que se desprende sin más la existencia de un crédito en dinero, esto es, aquella que documenta el reconocimiento por el deudor de la existencia de ese derecho de crédito. Sólo desde esa tradición puede comprenderse que el art. 685.2 hable de título o títulos de crédito, y de que de su tenor literal no se desprenda ninguna alusión a la hipoteca.

${ }^{8}$ Insiste este autor, en contra de lo que aquí se postula, que nos encontramos ante un procedimiento de base estrictamente registral, en el que lo importante es que la hipoteca conste inscrita y subsistente. Procedimiento de ejecución....ob, cit, pág. 152.

${ }^{9} \mathrm{Ob}$, cit, págs. 33 a 37.

${ }^{10}$ Este autor justifica las dudas existentes al respecto en estos términos: «...Parece que el legislador ha tenido presente que lo normal es que en la misma escritura se documenten el préstamo y la constitución de hipoteca, por eso habla de título de crédito. En el caso en que la escritura hipotecaria sea posterior a la escritura en que se contrae la obligación garantizada, el título ejecutivo es la escritura hipotecaria y no la de préstamo, por tanto, basta con presentar la primera, a no ser que éste no identifique de manera suficiente la obligación garantizada». Monserrat VALERo, Las novedades de la ejecución hipotecaria en la LEC 2000, Cuadernos Civitas, 2002, pág. 34.

${ }_{11} \mathrm{Ob}$, cit, pág. 34.

${ }^{12} \mathrm{Ob}$, cit, págs. 149 y 150 
En cualquier caso, en nuestra opinión, mantener que el título ejecutivo es el título de crédito y no la escritura de la hipoteca, resulta más coherente con el sistema instaurado por la propia LEC, que hace descansar la potencialidad ejecutiva en el título, pero no en la hipoteca.

El Registro no deja de tener cierta utilidad, pues delimita el alcance de la carga hipotecaria y con ello el ámbito de responsabilidad de los bienes hipotecados; sin embargo, no es idóneo para modular la fuerza ejecutiva del título. La inscripción en el Registro lo es de la hipoteca, no del título ejecutivo, y los extremos que consten en el asiento delimitan exclusivamente el alcance de responsabilidad de los bienes hipotecados, nunca las condiciones de ejecución del crédito, que son ajenas al Registro. Ni siquiera la inscripción del título ejecutivo constituye un requisito para su ejecutabilidad. Basta con que esté inscrita la hipoteca en términos que permitan al Juez determinar que el título ejecutivo cae dentro de su ámbito de cobertura. Este principio tiene visos de generalidad, por cuanto toda obligación es susceptible de asegurarse con hipoteca de máximo.

En todo caso, como es evidente, se hace necesario matizar que nos encontramos ante un título extrajudicial y esencialmente, ante un documento notarial ${ }^{13}$. En este sentido, MIRA ROS considera que cuando se trata de la ejecución de títulos no jurisdiccionales, el proceso tiene su punto de arranque en un documento cuya regularidad formal escapa al Derecho Procesal. La apertura del juicio ejecutivo pasa a depender de un concepto no procesal, sino de derecho documental, que convierte la legislación notarial en un mecanismo de integración de la normativa procesal. Ello no obstante, considera la autora citada, existe un desfase importante entre la legislación notarial y la legislación procesal, pues la norma procesal no ha avanzado al mismo ritmo que lo ha hecho la normativa notarial, lo que plantea ciertos problemas de coordinación ${ }^{14}$.

13 «Desde que en 1360 Pedro I dio a la ciudad de Sevilla el Ordenamiento sobre Administración de Justicia, el principal título ejecutivo extrajurisdiccional ha sido el documento notarial. La terminología ha cambiado, como es lógico, pasando de carta o alvala firmada del nombre de escribano, a escritura pública, pero lo permanente ha sido y sigue siendo que la garantía de la fe pública notarial con que se reviste a algunos documentos fue y es lo determinante de que a los mismos se les convierta en títulos ejecutivos. En este sentido el artículo 685.2 de la LEC se refiere a título o títulos de crédito, revestidos de los requisitos que esta Ley exige para el despacho de la ejecución, y el artículo $517.24 .^{\circ}$ a las escrituras públicas. Montero Aroca, J, ob, cit, pág. 380 .

${ }_{14}$ «.....tras la nueva Ley de Enjuiciamiento Civil, el notariado ha experimentado una profunda transformación que ha trastocado la técnica documental y, con ello, el sistema de títulos ejecutivos. Cuando el art. 517 de la LEC todavía menciona las pólizas 


\section{LA COPIA EJECUTIVA DE LA ESCRITURA PÚBLICA}

La escritura pública se inserta, en relación a la clasificación que distingue entre documento privado, documento público e instrumento público, dentro de estos últimos, pues se trata de documentos autorizados por Notario que van destinados desde el momento de su creación, a ingresar en un archivo (protocolo) integrado por documentos similares, los cuales se hallan en todo momento bajo custodia del Notario. La fuerza ejecutiva se atribuye con claridad a las escrituras públicas y no así a otro instrumento público cual es el acta notarial. El perfil diferenciador entre ambas clases de documentos radica en que las primeras se caracterizan por contener declaraciones de voluntad, actos jurídicos que impliquen prestación de consentimiento y contratos de toda clase. Por el contrario, el ámbito de las actas afecta, exclusivamente, a hechos jurídicos que por su carácter peculiar no pueden calificarse de actos o contratos ${ }^{15}$.

La eficacia de la escritura pública como título ejecutivo está condicionada en el art. 517 de la LEC $^{16}$ a que se trate de una primera copia y, excepcionalmente, servirá como título ejecutivo la segunda copia siempre que esté dada en virtud de mandamiento judicial y con citación de la persona a quien deba perjudicar, o de su causante, o que se expida con la conformidad de todas las partes. Con esta exigencia, se trata de evitar el riesgo que correría el deudor de existir varios títulos en circulación, pues podría verse abocado a una ejecución improcedente en base a un título inadvertido ${ }^{17}$.

intervenidas por Corredores de Comercio colegiados, esa profesión ha dejado de existir y esas pólizas que ahora intervienen los Notarios ya no circulan en original, igual que han desaparecido los asientos del Libro-registro de operaciones y los certificados con cargo al mismo. Tampoco la distinción entre primeras y segundas copias que formula el mimo precepto procesal en otro de sus apartados, para determinar cuándo la escritura notarial tiene fuerza ejecutiva, puede seguir manteniéndose después de las recientes reformas de la Ley y el Reglamento Notarial. Pero, sobre todo, ha habido un extraordinario avance de las nuevas tecnologías en el ámbito de las telecomunicaciones que han condicionado la actividad notarial, permitiendo el desarrollo del documento público electrónico. La incidencia de este documento como título ejecutivo, sin embargo, ni siquiera se contempla en la legislación procesal». MIRA ROS, C, La nueva regulación notarial de los títulos ejecutivos, Diario La Ley, n. ${ }^{\circ}$ 6931, 23 abril de 2008.

${ }^{15}$ Arrom Loscos, Comentarios a la Ley de Enjuiciamiento Civil..., ob, cit pág. 31.

${ }^{16}$ Igual que en la antigua legislación notarial, se sigue distinguiendo entre primeras y segundas copias para ligar la eficacia ejecutiva sólo a la primera copia y no a las posteriores.

${ }^{17}$ Ortell Ramos, La ejecución forzosa y la ejecución provisional (I), en Proceso Civil práctico (AA. VV), Tomo VII, La Ley, 2002. Por su parte, la Jurisprudencia menor se ha referido en reiteradas ocasiones al fundamento de la distinción entre primeras y segundas copias; a propósito de la legislación vigente antes de la reforma producida en 2006, la Sentencia de la AP de Huesca (n. ${ }^{\circ}$ 357/1997), de 30 de octubre alude dicha 
Sin embargo, MIRA ROS mantiene que no dejaba de ser cuestionable la antigüedad de la copia como criterio determinante de su carácter ejecutivo, pues obliga a custodiar estrechamente y por largo periodo de tiempo la primera copia obtenida, a priori, ante la eventualidad de que en un futuro tuviera que incoarse juicio ejecutivo ${ }^{18}$.

distinción y, además, reconoce la posibilidad de instar varias procedimientos ejecutivos con base en una misma escritura al afirmar: «...la razón de ser de esta distinción entre primeras y segundas copias estriba en excluir la posibilidad de que el acreedor intente varias ejecuciones basadas en diversas escrituras públicas que son copia de la misma escritura matriz. Pero no vemos inconveniente en que con base en una misma y única primera copia de escritura pública en que se documente un crédito, vencido, líquido y exigible, se sigan sucesivos procedimientos en tanto no se obtenga la satisfacción total del crédito. Lo que puede tener lugar si en un mismo documento se reconocen diversos réditos que venzan en diferentes fechas, o cuando habiendo varios deudores solidarios se ha dirigido infructuosamente la acción ejecutiva contra uno sólo de ellos y se intenta después, con base en la misma escritura pública, contra otro u otros». De otro lado, la SAP de Alicante (sección 4. ${ }^{a}$ 175/1998, de 12 de marzo, deniega el despacho de ejecución de una segunda copia porque no se había dado en virtud de mandamiento judicial y con citación de las partes a quienes debía perjudicar. En este sentido, sostiene la cita resolución judicial que un acuerdo de partes inserto a modo de cláusula contractual, en cuya virtud se pacta que la parte acreedora podrá obtener copia con valor ejecutivo, es contrario al art. 1429.1 de la LEC de 1881 (entonces vigente) y no puede modificar los requisitos que la ley exige para despachar ejecución. En definitiva, según la AP las partes por si solas no puede pactar que las copias que en el futuro se obtengan, tengan eficacia ejecutiva. Finalmente, respecto de la expedición de segundas copias con efectos ejecutivos en virtud de mandamiento judicial, la SAP de Granada (sección 3. ${ }^{\text {a }}$ 927/1998, de 1 de diciembre, alude a las distintas posturas doctrinales existentes: «a) Los otorgantes de la escritura o sus sucesores comparecen ante el Notario que tenga el protocolo mostrando la conformidad con la expedición de la segunda copia, que el Notario puede expedir a tenor de los artículos 18 de la ley del Notariado y 234 de su Reglamento, pero la cuestión es si esa segunda copia es título ejecutivo ya que si nos atenemos a los términos de la Ley no se ha dado en virtud de un mandamiento judicial, y sin embargo, no puede olvidarse que la expedición goza de garantías en cuanto todos los otorgantes comparecen ante el Notario manifestando su conformidad con la misma. En la doctrina Prieto Castro se pronunció por la eficacia ejecutiva del título así expedido, sin necesidad de que se emitiera en virtud de mandamiento judicial y, Fernández, ateniéndose a los términos del precepto y a su interpretación restrictiva se inclina por la falta de fuerza ejecutiva de este tipo de segundas copias. b) Los otorgantes de la escritura han mostrado la conformidad con la expedición de segundas copias, no por comparecencia ante Notario en cuyo poder se encuentra el protocolo, sino en otro documento auténtico, normalmente en la escritura matriz. Este último, es precisamente el supuesto ante el que nos encontramos, el haber pactado las partes, que la segundas o posteriores copias de la escritura, podrán tener idénticos efectos ejecutivos que la primera, haciéndose constar así por el Notario en el pie y nota su expedición, para lo cual las partes comparecientes otorgan su consentimiento expreso e irrevocable....» Sobre la insuficiencia de la copia simple de escritura de préstamo para poder despachar ejecución, Auto 11/2008, de la AP de Murcia (sección 3. ${ }^{\text {, }}$, de 1 de febrero.

${ }^{18} \mathrm{El}$ acreedor asumía con ello una carga de custodia por un plazo exorbitante. Guardar un papel, sin perderlo, durante más de treinta o cuarenta años, que es el plazo común de tantos préstamos hipotecarios, puede parecer excesivo. En la prácti-

(C) UNED. Revista de Derecho UNED, núm. 14, 2014 
De ahí que se generalizara el pacto, especialmente, si la acreedora era una entidad financiera, de permitir al acreedor, con la aprobación irrevocable del deudor, de solicitar y obtener cuantas copias quisiera, primeras o segundas, todas con idéntico valor ejecutivo. ${ }^{19}$ Vuelve a decantarse la legislación a favor de quien de por sí asume la posición más sólida en la relación jurídica crediticia, en tanto el deudor se encuentra a expensas de las exigencias, normalmente, de la entidad financiera con la que contrató.

Puestas así las cosas, la nueva legislación notarial, con mejor técnica, manteniendo el criterio restrictivo en la expedición de copias ejecutivas, reconoce tan solo al acreedor la posibilidad de obtener una copia y ninguna más, salvo por mandato judicial o conformidad de todas las partes. La salvedad está en que ahora únicamente será ejecutiva la copia que se expida con tal carácter, al margen de su cronología, por lo que es habitual que el acreedor sólo obtenga una copia autorizada sin carácter ejecutivo y únicamente obtenga la copia ejecutiva cuando planteada la situación de impago se proponga demandar por vía ejecutiva ${ }^{20}$.

ca el acreedor rehusaba que se le diese, en principio, ninguna copia expedida a su nombre, pactando con frecuencia que al acreedor se le entregase la copia expedida a nombre del deudor, a fin de preservar el primero su derecho a instar, llegado el caso, por no haberla solicitado hasta entonces, esa primera copia a su nombre dotada de fuerza ejecutiva. La nueva regulación notarial de los títulos ejecutivos. Diario La Ley n. ${ }^{\circ}$ 6931, 23 de abril de 2008, Año XXIX.

${ }^{19}$ Posibilidad que se encuentra abiertamente recogida en los arts. 24 de la Ley Notarial y 234 del Reglamento Notarial, a pesar de los reparos iniciales que encontró en un sector de la doctrina. No obstante, mantiene ARROM Loscos que alguna precisión de importancia cabe hacer en materia de segundas copias respecto al art. 234 del $\mathrm{RN}$, que prevé la expedición de segundas copias o posteriores copias al amparo del consenso de los perjudicados. Para ésta autora, la mencionada norma reglamentaria carece de validez por aplicación del art. 1.2 del CC, al contradecir a otra de rango superior cual es el art. 517 de la vigente LEC. En efecto, el art. 234 RN permite la expedición de segundas copias sin requerir mandamiento judicial, ni citación de parte o causahabientes a quien deba perjudicar. Por tanto, se debe concluir que las copias creadas al amparo de lo establecido en la norma reglamentaria carecerán de fuerza ejecutiva. Comentarios a la Ley de Enjuiciamiento....ob, cit, pág. 33.

${ }^{20}$ No obstante, MiRa Ros afirma que con la nueva normativa, la pérdida de una copia ejecutiva resulta tan perturbadora como antes, al depender su recuperación por el acreedor de la improbable conformidad del deudor o, subsidiariamente, del resultado de una decisión judicial. Si se quiere de verdad conjurar el peligro de desaparición de la copia y, con ella, del título ejecutivo, nuestro legislador debía haber avanzado un paso más, convirtiendo en ejecutiva únicamente la copia notarial electrónica. Esa copia ejecutiva remitida directamente desde la Notaria al Juzgado por vía electrónica no tendrá riesgo de pérdida. Si así fuera, llegado el caso, con la demanda no se acompañaría más que la copia en papel en poder del acreedor, pero a la vista de la cual el Juez podrá, a petición del acreedor, solicitar del Notario corres- 
En este punto, resulta obligada la referencia a la reforma que experimentó el art. 17.4 de la Ley del Notariado merced a la Ley 36/2006, de 29 de noviembre de medidas de prevención del fraude fiscal ${ }^{21}$. En efecto, el precepto, en su nueva redacción, encierra una importante novedad al separar conceptos como primera copia y título ejecutivo. Ya no son conceptos plenamente coincidentes, de manera que puede existir una primera copia sin efectos ejecutivos y una segunda copia con efectos ejecutivos.

En consecuencia, la primera copia, considerada en sí misma, sin hacer constar que se ha expedido con carácter ejecutivo, ha perdido su eficacia jurídica fundamental, su fuerza ejecutiva.

Concretamente, en relación a las escrituras públicas, rige lo dispuesto en el artículo 233 del Reglamento Notarial, reformado para adaptarlo a la nueva redacción del art. 17.2 de la Ley del Notariado en la formulación que le da la Ley 36/2006. Por tanto, el carácter ejecutivo de las copias ya no viene determinado por la fecha de expedición sino por su otorgamiento con tal carácter. Es decir, no por su condición de primera o segunda copia, sino por haber sido expedida expresamente con carácter ejecutivo. Ha desaparecido cualquier referencia a la antigua distinción entre "primera» $\mathrm{y}$ "segundas o posteriores copias», de modo que solamente hay copias expedidas con carácter ejecutivo y copias expedidas sin tal carácter.

Lo anterior resulta de aplicación a las escrituras otorgadas tras la entrada en vigor de la Ley 36/2006; aun así, se han planteado problemas en relación a las escrituras concertadas con anterioridad, pero cuya ejecución se insta con posterioridad, respecto de las cuales se aplica el sistema anterior, es decir, el que estaba vigente antes de la reforma producida por la Ley 36/2006, lo que ha de suponer que las primeras copias expedidas con anterioridad a la entrada en vigor de esta reforma no pueden perder su eficacia ejecutiva ${ }^{22}$. En este sentido,

pondiente la remisión de una copia electrónica con efectos ejecutivos, a fin de que el Juez la incorpore a los autos. La nueva regulación normativa... Ob, cit.

${ }^{21}$ Establece textualmente: «Es primera copia el traslado de la escritura matriz que tiene derecho a obtener por primera vez cada uno de los otorgantes. A los efectos del artículo 517.2.4. ${ }^{\circ}$ de la Ley 1/2000, de 7 de enero, de Enjuiciamiento Civil, se considerará título ejecutivo aquella copia que el interesado solicite que se le expida con tal carácter. Expedida dicha copia el Notario insertará mediante nota en la matriz su fecha de expedición e interesado que la solicitó».

${ }^{22}$ Así lo resolvió la Junta Directiva del Ilustre Colegio Notarial de Madrid en sesión celebrada el día 22 de febrero de 2010 que divulgó nota informativa al respecto, tras las múltiples dudas suscitadas en torno a los títulos ejecutivos. Entre otras consideraciones, la mencionada nota afirma que la nueva regulación es clara y su aplicación a las escrituras otorgadas tras la entrada en vigor de la ley 36/2006 es indudable. 
el Auto de la AP de Barcelona, de 9 de junio de 2011(sección 11. ${ }^{a}$, alude a la cuestión y después de examinar los diversos criterios existentes afirma, en el caso concreto, que al tratarse el título de un documento posterior a la reforma de la Ley del Notariado de 2006 y de su Reglamento de 2007, se exige no sólo la mención por el fedatario público de que es primera copia y de su carácter ejecutivo, sino de que se ha solicitado con esa finalidad. Requisitos que no tienen únicamente alcance notarial, sino procesal.

Igualmente, el Auto de la AP de Madrid (sección 8. ${ }^{a}$, de 23 de mayo de 2011, resuelve la denegación del despacho de la ejecución por no constar en la primera copia de la escritura pública que se hubiese expedido con eficacia ejecutiva; en este sentido, afirma que no era exigible como requisito o presupuesto de la eficacia del título que la entidad tuviera que solicitar al Notario la expedición de la copia con carácter de título ejecutivo y que dicho fedatario insertara mediante nota en su matriz la fecha de la expedición e interesado que la solicitó. La regulación de la Ley 36/2006 no contradice la regulación anterior, sino que la sustituye para aquellas escrituras públicas que se otorguen desde su entrada en vigor, lo que no autoriza a aplicar retroactivamente esa Ley a escrituras otorgadas antes del 1 de diciembre de $2006^{23}$.

Pero, con respecto a las escrituras otorgadas antes rige el sistema anterior. Afirma la nota: «En el sistema anterior, el carácter ejecutivo de las copias de las escrituras estaba determinado por la condición de primera copia y segunda o posteriores, que carecían de fuerza ejecutiva. Esto suponía que la copia expedida con la mención de "primera» a instancia del acreedor era la única que podía servir de base para instar el juicio ejecutivo. Incluso si se expedía una segunda o posterior copia, era necesario indicar que la misma carecía de efectos ejecutivos. De ahí que el art. 517.2.4. ${ }^{\circ}$ de la LEC dijese que sólo tendrían aparejada ejecución las escrituras públicas con tal que sean primera copia.

${ }^{23}$ En sentido coincidente se pronuncian resoluciones de la misma Audiencia Provincial de fecha 11 de junio de 2010 (sección 13. a , 7 de julio de 2010 (sección $14 .^{\mathrm{a}}, 18$ de octubre de 2010 (sección 20. ${ }^{\mathrm{a}}$ y 14 de diciembre de 2010 (sección 13. ${ }^{\mathrm{a}}$, entre otras. También, Auto de la AP de Madrid, de 30 de mayo de 2011 (sección 8. $^{\text {a }}$ y Auto 98/2010 de 13 de abril. Después de la reforma producida por la Ley 36/2006, de 29 de noviembre, únicamente es título ejecutivo la copia de la escritura que el interesado ha solicitado que se expida con tal carácter y así se ha hecho, insertando el Notario en la matriz la fecha de expedición y el interesado que la solicitó. Entre otros, Autos de la AP de Madrid 267/2010 de 18 de octubre (sección 20. ${ }^{\mathrm{a}}$ y Auto 465/2011 de 16 de junio (sección 12. ${ }^{\text {a }}$; Auto de la AP de Sevilla (sección 6. ${ }^{\text {a }}$ 115/2011 de 23 de septiembre y Auto de la AP de Barcelona (sección 1. ${ }^{a}$ 76/2012 de 16 de abril. 


\section{LA INTEGRACIÓN DEL TÍTULO EJECUTIVO: EL SUPUESTO DE LA HIPOTECA FLOTANTE}

$\mathrm{El}$ art. 685 LEC establece que en caso de que no pudiese presentarse el título inscrito ${ }^{24}$, deberá acompañarse con el que se presente certificación del Registro que acredite la inscripción y subsistencia de la hipoteca. Como quiera que la documentación presentada junto con la demanda ejecutiva es de suma importancia, pues justifica la pretensión ejecutiva, la problemática se suscita esencialmente en aquellos supuestos en que hay que integrar el título. En la mayor parte de las hipotecas ordinarias, el título ejecutivo coincide habitualmente con el título constitutivo, en tanto la obligación garantizada y la garantía (hipoteca) se formalizan en una misma escritura.

Sin embargo, es más compleja la problemática ejecutiva de las hipotecas de seguridad, especialmente cuando responden al tipo de hipotecas flotantes ${ }^{25}$. Dicha complejidad deriva de la dificultad de fijar con precisión en el momento de la ejecución la existencia y cuantía de la deuda, siendo necesario en ese caso verificar lo que se ha dado en llamar integración del título ${ }^{26}$.

${ }^{24}$ Habla ahora la ley de título inscrito cuando anteriormente lo había hecho de título de crédito. Y es que la confusión a la que induce el legislador es superlativa, demostrativa de la continua identificación histórica que vienen padeciendo crédito e hipoteca; en definitiva, obligación garantizada y garantía.

${ }^{25}$ Es aquella por la que se pacta una inclusión en la cobertura de un número ilimitado de obligaciones que no vienen determinadas cuando se constituye la hipoteca pero que son determinables conforme a criterios de integración pactados por las partes. Desde el punto de vista registral, la hipoteca flotante es una modalidad de la hipoteca de máximo que se caracteriza por asegurar una pluralidad de obligaciones, a diferencia de la hipoteca ordinaria, de cuyo importe, cuantía y existencia da fe el Registro de la Propiedad. Antes de la modificación producida por la Ley 41/2007 en la Ley Hipotecaria, la hipoteca únicamente podía garantizar una obligación principal y sus obligaciones accesorias como intereses y costas. Si se quería garantizar dos obligaciones principales distintas había que constituir dos hipotecas distintas. $M e$ mento Experto. Hipoteca: operaciones de financiación y refinanciación. Ed. Francis Lefebvre, 2001, pág. 135.

${ }^{26} \mathrm{El}$ método de integración cuyo empleo ha sido más controvertido, a la par que generalizado en la práctica de las entidades financieras, es el constituido por la certificación unilateral del saldo debido por parte de la entidad acreedora, en aquellos supuestos en que habiéndose formalizado el contrato en escritura pública o póliza intervenida, se haya pactado en el título que la cantidad exigible en caso de ejecución será la resultante de la referida liquidación unilateral, practicada de acuerdo con lo convenido por las partes en el título ejecutivo. Es a éste sistema al que se acoge el legislador en el art. 153 bis LH, al autorizar a las partes para que la liquidación de la cantidad ejecutivamente exigible se determine como consecuencia de la liquidación efectuada unilateralmente por la entidad financiera, «en la forma convenida por las partes en la presente escritura». A juicio de CANLE FERNANDEZ, tal previsión es coherente con el valor probatorio atribuido a los libros de los comerciantes,(art. 31 Cód.

(C) UNED. Revista de Derecho UNED, núm. 14, 2014 


\section{III.1 La ejecutabilidad de la hipoteca flotante por el proceso de ejecución hipotecaria}

Con respecto al caso concreto de la novedosa figura de la hipoteca flotante, recuerda PAZ-ARES ${ }^{27}$ las dos cuestiones que han sido objeto de debate más intenso en el seno de la doctrina. De un lado, si son susceptibles o no de ser objeto del procedimiento especial de ejecución hipotecaria; de otro, en caso afirmativo, cómo ha de acreditarse el título ejecutivo.

En relación con la primera cuestión expuesta, hay que recordar que tradicionalmente se negó esta posibilidad, es decir, se rechazaba la ejecutabilidad de las hipotecas de seguridad por el procedimiento de ejecución hipotecaria, incluso por el extrajudicial. La DGRN rechazaba esta opción basándose en la indeterminación de la deuda y de la cuantía.

Sin embargo, la propia DGRN cambia de criterio al reconocer más tarde que la indeterminación de la deuda no constituye un obstáculo para la utilización del procedimiento de ejecución sumario, pues es posible que el acreedor pueda obtener con posterioridad a la constatación tabular de la garantía un título suficiente para despachar ejecución. ${ }^{28}$

Con todo, la cuestión dista de ser pacífica. Autores, como DE LA OLIVA, siguen negando, una vez promulgada la vigente LEC, que este tipo de hipotecas flotantes puedan ejecutarse por el procedimiento regulado en los arts. 681 y siguientes al afirmar que no existen previsiones especiales sobre la forma de establecer, a efectos de ejecución, la existencia e importe de la deuda, por lo que, como regla general, será necesario un previo proceso declarativo para determinar con precisión el alcance de la obligación garantizada.

de Comercio) la posibilidad de convenir inter partes la eficacia ejecutiva de la certificación unilateral de saldo (art. 1255 CC), la ineludible notificación de la misma al deudor con carácter previo al inicio del procedimiento hipotecario, y la posibilidad de oposición de este último de acuerdo con lo dispuesto en los cuatro últimos apartados del art. $153 \mathrm{LH}$, argumentos todos ellos válidos con anterioridad a la reforma, y que han determinado la definitiva extensión por parte del legislador del procedimiento de integración extraregistral del título ejecutivo ya previsto respecto de la hipoteca en garantía de cuenta corriente de crédito a la nueva hipoteca flotante. CANLE FERNANDEZ, Consideraciones sobre la hipoteca flotante: el nuevo artículo 153 bis de la Ley Hipotecaria, Revista Critica de Derecho Inmobiliario, n. ${ }^{\circ} 723$, págs. 299 a 364.

${ }^{27} \mathrm{Ob}$, cit, págs. 186 y siguientes.

28 Todas las resoluciones a las que se alude son de la década de los 90 y se enumeran en Hipotecas flotantes, AZOFRA, pág. 1221. 
En ese sentido, PAZ-ARES reconoce que, en efecto, el art. 153 bis de la LH, regulador de la hipoteca flotante, no se ocupa apenas de su ejecución, pero, a pesar de ello, reconoce sin ambages la potencialidad ejecutiva de esta hipoteca al sostener que la acción hipotecaria podrá ser ejercitada de conformidad con los arts. 129 y 153 de la LH y concordantes de la LEC. Luego, en términos concisos, la Ley opta por reconocer la ejecutabilidad de la hipoteca global o flotante. La misma afirmación puede deducirse de lo dispuesto en el mismo precepto cuando alude al pacto de liquidez en caso de ejecución.

Por su parte, MUNIIZ ESPADA ${ }^{29}$ se ocupa de este mismo aspecto, y partiendo de la innegable posibilidad de ejecutar esta hipoteca, afirma que para instar la ejecución, ya que ni el título, ni el Registro dan cuenta de la existencia de las deudas o de su cuantía, va de suyo la integración del título para proceder ejecutivamente contra la finca hipotecada. En efecto, como en el título constitutivo de la hipoteca no se determina, ni está especificada la obligación u obligaciones garantizadas, podrá pactarse en el título que la cantidad exigible en caso de ejecución sea la resultante de la liquidación efectuada por la entidad financiera acreedora en la forma convenida por las partes en la escritura, a semejanza del art. $153 \mathrm{LH}^{30}$; así lo dice el art. 153 bis LH, circunstancia que es de perfecta aplicación a la hipoteca flotante, a juicio de MUÑIZ, por dos razones: primera, porque para el legislador es la forma más fácil de resolver el problema (aplicando la analogía), y, segunda razón, además así se viene haciendo en la práctica. Se incluyen como cláusulas de una hipoteca abierta que se considera como cantidad liquida y exigible a efectos del ejercicio de acciones judiciales la que resulte de dicha liquidación efectuada por el banco en la forma convenida por las partes en el propio título. El saldo por liquidación de la cuenta de crédito se acreditará mediante certificación del banco a los efectos del ejercicio de cualquier clase de acción ejecutiva que le competa.

${ }^{29}$ La hipoteca de máximo del art. 15 bis Ley hipotecaria y la finalidad de los préstamos y créditos hipotecarios en la ley del mercado hipotecario (Art. 11.4 y 12.1 de la Ley 41/2007), en La reforma del mercado hipotecario y otras medidas financieras en el contexto de la crisis económica. Coordinadores: MuÑIz EsPADA, NASARRE AzNAR y SÁNCHEZ JORDAN. Ed, Edisofer S. L Madrid, 2009. págs. 247 y siguientes.

${ }^{30}$ Para ello el acreedor abrirá y llevará en sus libros una cuenta especial donde se especifique el importe del principal, intereses ordinarios, comisiones, honorarios, costes, intereses indemnizatorios, costes adicionales y demás sumas debidas por el deudor, dividida en subcuentas para cada una de las obligaciones. De igual modo, constaría el consentimiento del acreedor si la cuenta que se lleva de las distintas operaciones financieras o el reconocimiento de cada nueva obligación se firma por ambos. 


\section{III.2. La necesaria integración del título}

Siguiendo con esta cuestión, que trata de clarificar cómo ha de acreditarse el título ejecutivo, toda vez que se admite la posibilidad de ejecución de la hipoteca flotante, hay que partir de la inexistencia de normas especiales en la LEC; por consiguiente, como quiera que lo que se ejecuta es una o varias obligaciones dinerarias, la acción ejecutiva ha de fundarse en un título que lleve aparejada ejecución, del que resulte la deuda.

El título ejecutivo puede nacer con anterioridad o coetáneamente a la garantía. Así ocurre en los supuestos en los que la hipoteca, además de asegurar obligaciones futuras, garantiza alguna obligación preexistente o simultánea a la hipoteca. No obstante, en la mayoría de casos de hipoteca global, lo habitual es que la garantía surja con anterioridad a las obligaciones o relaciones jurídicas a que ha de dar cobertu$\mathrm{ra}^{31}$. En consecuencia, el título constitutivo consistiría en un contrato normativo, en previsión de relaciones crediticias futuras, con reserva de rango a favor del acreedor, pero que carece de toda virtualidad ejecutiva por sí solo. En este supuesto, y en todos aquellos en que la escritura de constitución de hipoteca no acredite la pluralidad de obligaciones garantizadas, su ejecución requiere la presentación de un título ejecutivo distinto de escritura constitutiva, que justifique el nacimiento o existencia de las obligaciones que aquella escritura no ampara; ningún otro documento puede suplir su falta. Ni siquiera el documento que se genere, en aplicación de la previsión contractual que determina la forma de cálculo del saldo final garantizado, o cualquier otro documento meramente liquidatorio. Aunque esté contrastado notarialmente, no puede sustituir, sino acaso complementar, la presentación del título o títulos de crédito a que se refiere el art. 685.2 de la LEC $^{32}$.

${ }^{31}$ Incluso es probable, al incardinarse esta figura en el ámbito de los negocios bancarios, que se generalice el supuesto de que la hipoteca se formalice en una escritura en la que las partes establezcan, además de las condiciones de la misma, el cuadro marco por el que se han de regular las futuras relaciones crediticias aseguradas, pero sin que surjan todavía obligaciones a cargo del deudor, ni que la persona a cuyo favor se constituya asuma compromiso alguno de concesión del crédito. Paz-ARES, Ob, cit, pág. 188 .

${ }^{32}$ Así lo corrobora MiRa Ros cuando afirma que la certificación registral acreditando la existencia de la hipoteca constituye un documento complementario que debe acompañarse a la demanda para la integración del título ejecutivo en determinados supuestos, cuando no pudiese presentarse el título inscrito, dice el art. 685 de la LEC, o para la debida constitución de la litis, pero que no la fundamenta, ni puede reemplazar al título. La autora citada recuerda en este sentido que, bajo la normativa anterior, hubo autores que enarbolaron la certificación registral como título ejecutivo propio. Entendiendo que la inscripción constitutiva de la hipoteca bastaba para prestar fundamento al ejercicio de la acción hipotecaria. Pero ello era porque se partía de 
Admitir lo contrario supondría tanto como quebrar el sistema en que se asienta la vigente Ley procesal en materia de ejecución, en el que no hay ejecución sin título; documentos como la certificación bancaria o el documento fehaciente no son documentos idóneos para suplantar al título ejecutivo, sino meramente para complementarlo ${ }^{33}$.

\section{EL DOCUMENTO FEHACIENTE COMO COMPLEMENTO DE LA CERTIFICACIÓN BANCARIA}

Más controvertida es la necesidad de que se acompañe a la certificación bancaria que determina la liquidez del título el denominado documento fehaciente. Este documento es complejo y comprende un actuación de fedatario (el Notario) consistente en un testimonio de coincidencia de la forma en que se ha practicado la liquidación con la pactada por las partes ${ }^{34}$.

una concepción del procedimiento judicial sumario como mecanismo de tutela ejecutiva, no del crédito, sino de un derecho real inscrito que permitía la ejecución directa sobre los bienes sujetos a la acción del acreedor hipotecario, si bien, para la realización judicial de ese derecho inscrito, la pretensión procesal tenía entonces que tener encaje exacto en el contenido del asiento. Hacia un enfoque procesal....ob, cit. pág. 13.

${ }^{33}$ En palabras de Paz-AREs, «ni puede despacharse ejecución si no existe título ejecutivo que justifique o del que resulte la deuda, ni puede expedirse el documento fehaciente sin que se aporte aquél, para contrastar la liquidación efectuada por el acreedor. La autonomía contractual en materia ejecutiva tiene un campo de actuación muy limitado. Sólo la materia estrictamente liquidatoria es parcialmente disponible. Fuera de este ámbito no es competente, ni para convertir a los documentos de liquidación en título ejecutivo, ni tampoco para conferir virtualidad ejecutiva a ningún otro documento del que pueda resultar una obligación, distintos de los fijados legalmente. Ob, cit, pág. 190.

${ }^{34}$ El Tribunal Supremo, en la importante Sentencia de 16 de diciembre de 2009(n. ${ }^{\circ}$ recurso 2114/2005), mantiene la validez de este pacto en el Fundamento de Derecho sexto. Afirma que el denominado pacto de liquidez o de liquidación es válido porque es un acto procesal para acreditar uno de los requisitos procesales del despacho de la ejecución, cual es la liquidez o determinación de la deuda y, por consiguiente, para poder formular la reclamación judicial de la misma. Esta es la finalidad del pacto, despacho de ejecución, y, por lo tanto, no obsta a la impugnación de la cantidad expresada en la certificación bancaria mediante la oposición correspondiente y sin alterar las normas en materia de carga de la prueba. La previsión legal es clara y excusa de cualquier otra información contractual al respecto y así lo vienen entendiendo los tribunales, por lo que no se infringen los arts. $2.1 \mathrm{~d}$ ) y 10.1 a) de la LGDCU, ni su DA $1 .^{a}$ apartado $14 .^{a}$ Por su parte, CASTILlEJo MANZANARES considera que el legislador no ha querido limitar la labor del fedatario a constatar que el procedimiento liquidatorio aplicado es el pactado en el título ejecutivo, sin que sea preciso entrar en el contenido de la propia liquidación. Sino que su función incluye un juicio sobre la adecuación del contenido de la liquidación a los términos fijados en el título ejecutivo. En este juicio que ha de llevar a cabo el fedatario no se le puede exigir que realice una verdadera auditoria, puesto que el legislador no impone al acreedor que en- 
La LEC al regular la liquidación del saldo de operaciones resultantes de contratos formalizados en escritura o póliza permite (arts. 572 y 573) que se efectúe por el acreedor, sea o no entidad bancaria, siempre que medie pacto y que se acompañe el documento fehaciente. Los preceptos aludidos, en sede de ejecución forzosa, son de general aplicación y, en particular, el art. 685.2 LEC, referido a la ejecución hipotecaria, remite directamente a ellos. Sin embargo, con la Ley 41/2007, tal y como recuerda PAZ-ARES, vuelve a surgir la duda en este punto. El art. 153 bis LH, atinente a las hipotecas flotantes, mantiene la validez del pacto de liquidación por la entidad acreedora y señala que la acción hipotecaria podrá ejercitarse de conformidad con lo previsto en el art. 153 del mismo cuerpo normativo. Pero, según este autor, no hay datos relevantes para sostener un cambio de sistema y el reenvío al art. 153 LH no tiene más finalidad que la de dar cabida al doble sistema de liquidación característico de esta norma, la doble libreta y la certificación bancaria. A su juicio, las especialidades del proceso hipotecario no excluyen la exigencia del documento fehaciente ${ }^{35}$.

Para MIRA ROS, si hubiera que poner un ejemplo de rotundo desequilibrio entre las respectivas posibilidades formales de defensa que ostentan las partes, cuando se trata de ejecución de créditos en el sistema financiero, ese es precisamente el que encierra el art. 572.2 $\mathrm{LEC}^{36}$. El hecho de que la cantidad finalmente exigible, por la que

tregue siempre y en todo caso los justificantes de las diversas partidas de cargo y abono, sino tan solo cuando lo estime conveniente. Por ello, concluye, no se puede imponer al fedatario que compruebe la procedencia y justificación de cada uno de los asientos de la cuenta y sus correspondientes fechas de valoración. La liquidez de la deuda como requisito del título ejecutivo extrajudicial. En La ejecución civil, Dir.: MoRENo CATENA. CGPJ, Centro de documentación judicial. Estudios de Derecho judicial 53/2004, pág. 491

${ }^{35}$ Afirma Paz-AREs que la solución contraria nos llevaría a un resultado doblemente absurdo: exigir el documento fehaciente para todas las ejecuciones hipotecarias (art. 685.2 LEC), salvo para aquellas en que la liquidación es visiblemente más complicada, como en el caso de las cuentas corrientes de crédito, o respecto de la cesta de relaciones crediticias que pueden ser objeto de cobertura de la hipoteca global; y eliminar una garantía del sistema de liquidación cuando es efectuada por el propio acreedor en la ejecución hipotecaria, pese a que puede afectar a un tercero que no ha consentido esa forma de liquidación. La obligada lectura garantista de los procedimientos de ejecución que se deduce de la jurisprudencia del TC, así como el criterio restrictivo que debe presidir la interpretación de las normas especiales que se apartan de la regulación general contenidas en el procedimiento de ejecución ordinario, contribuyen decisivamente a eliminar toda sombra de duda sobre el documento fehaciente, como presupuesto de ejecutividad de la certificación del saldo garantido en las ejecuciones hipotecarias. En todas, especialmente en las de obligaciones cubiertas por una hipoteca flotante. Ob, cit, págs. 193 y 194.

36 «2. También podrá despacharse ejecución por el importe del saldo resultante de operaciones derivadas de contratos formalizados en escritura pública o en póliza in- 
habrá de despacharse ejecución, se fije unilateralmente por el acreedor, sin audiencia del deudor, es un caso paradigmático de desequilibrio $^{37}$. E indicativo, por añadidura, una vez más, de la clara indefensión en que se encuentra prácticamente desde el inicio de la relación contractual, el cliente-deudor, pues a pesar de que se revista bajo el manto de la autonomía de la voluntad, dicho pacto es de todo menos un pacto en sentido estricto y la exigencia de documento fehaciente que corrobore que la liquidación se ha efectuado del modo indicado en el título no ofrece ninguna garantía adicional para el deudor, más bien, a favor del propio acreedor en el sentido de que no se le denegará la ejecución por un defecto formal ${ }^{38}$.

MIRA ROS recuerda, en este sentido, que la hipótesis más habitual en la práctica es que la liquidación de la deuda se desvincule

tervenida por corredor de comercio colegiado, siempre que se haya pactado en el título que la cantidad exigible en caso de ejecución será la resultante de la liquidación efectuada por el acreedor en la forma convenida por las partes en el propio título ejecutivo. En este caso, sólo se despachará ejecución si el acreedor acredita haber notificado previamente al ejecutado y al fiador, si lo hubiere, la cantidad exigible resultante de la liquidación».

${ }^{37} \mathrm{La}$ introducción de este engranaje procesal en el sistema financiero ha sido progresiva. Arranca de una orden ministerial de 1950 que extendió a la banca privada el privilegio otorgado dos años antes al Banco de España, consistente en que la determinación del saldo del crédito por la banca acreedora "hará fe en juicio». Como se trata de un privilegio bancario difícil de justificar en el nuevo sistema de garantías procesales que se instaura después de la Constitución, una Ley de 1984, de reforma Urgente de la legislación procesal, trató de darle acogida mediante una nueva redacción del art. 1435 de la anterior Ley de Enjuiciamiento Civil, exigiendo que se tratase de una certificación de saldo emitida por una entidad financiera (no un simple acreedor) con base en un pacto de liquidación contable consentido por el deudor en el propio título, siempre que además se aportase algún documento fehaciente acreditativo de que la liquidación se había practicado en la forma pactada en el título ejecutivo. La norma, una vez afirmada su constitucionalidad por el Alto Tribunal en sentencia de 10 de febrero de 1992, ha sido trasladada íntegramente a los actuales arts. 572 y 573 de la LEC, sin más cambios que su explicita aplicabilidad ahora a todo acreedor, sea o no entidad financiera, y a toda deuda, derivada tanto de créditos como de préstamos. MIRA Ros, La creciente morosidad en ciernes: algunos problemas en la ejecución de créditos. Revista el Notario del siglo XXI, n. ${ }^{\circ} 18$.

38 Opinión opuesta es la que mantiene Domínguez Romero para quien el pacto de liquidación se hace en beneficio del acreedor pero también del propio deudor. Afirma: «..cierto es que estamos ante contratos que se articulan en su mayoría mediante condiciones generales predispuestas por el acreedor, esto es, contratos de adhesión, donde seria discutible la existencia de verdadera voluntad negociadora del clausulado por parte del deudor, que habitualmente se adhiere en bloque al conjunto de condiciones generales, sin prestar demasiada atención a la cláusula que recoja esa concreta forma de determinación de la cantidad exigible. Pero no es menos cierto que el pacto de liquidación, aun cuando en su existencia se hace en beneficio del acreedor, a quién beneficia fundamentalmente es al deudor en cuanto a los requisitos y garantías de su validez, según entiende la Jurisprudencia, razón por la cual sostiene que dicho pacto obliga a los contratantes y, por ende, debe respetarse su operatividad». Ob, cit, pág. 83.

(C) UNED. Revista de Derecho UNED, núm. 14, 2014 
cronológicamente del título público, dada la sofisticación de los productos y servicios financieros. La intervención del fedatario implica una garantía formal, sobre todo si quien la extiende es un experto contable, pero no es suficiente para dotar a la certificación del saldo que emite la entidad la misma presunción de veracidad inherente a los títulos notariales que llevan aparejada ejecución. Ahora bien, mantiene la autora que se trata de un documento fehaciente muy disminuido y con efectos difuminados, dada la exigencia del art. 573.1 LEC de tener que acompañar además el extracto de las partidas de cargo y abono ${ }^{39}$, como si sobre el acreedor pesara la carga de probar en juicio los asientos contables y el documento fehaciente no le dispensara de ello por no dar fe de la exactitud de la cuenta. Para MIRA ROS, la razón de un documento fehaciente de tan poca fe hay que buscarla en que la presunción de exactitud inherente a la fe pública notarial se entiende sólo a los hechos que el Notario puede percibir por sus sentidos y también a los juicios que éste puede formular con arreglo a las leyes, que son el juicio de capacidad, el juicio de suficiencia de la representación y el juicio de adecuación, en general, al ordenamiento jurídico, pero son, en todo caso juicios jurídicos. En cambio, que una cuenta o una liquidación contable esté bien hecha o lo esté en la forma pactada contractualmente, envuelve un juicio matemático, no cubierto, en puridad, por la fe pública notarial ${ }^{40}$.

FERNANDEZ DE CORDOVA, por su parte, puntualiza que el título puede reservar al acreedor la facultad de liquidar el saldo a efectos del despacho de la ejecución, pero no, en cambio, la de convertir el resultado de la liquidación unilateralmente realizada en prueba plena e incontrovertible. Insiste, asimismo, en la importancia de una intervención activa del Notario en el proceso de verificación y en el celo especial que debe poner, por cuanto puede solicitar cuantas aclaraciones adicionales resulten necesarias para efectuar las comprobaciones técnicas oportunas a una adecuada comprobación ${ }^{41}$.

${ }^{39}$ Sostiene Castillejo Manzanares que con este documento se trata de evitar la indefensión en que puede colocarse al deudor cuando no estando de acuerdo con la liquidación efectuada por el acreedor, no puede impugnarla por no encontrarse en su poder las diversas partidas del debe y del haber utilizadas por el acreedor para fijar el saldo deudor. De hecho, si se alega el pago de partidas no recogidas, la prueba no resulta difícil; pero si se alega que no se ha obligado, tiene la carga de probar la inexistencia de la obligación para poder oponerse a la ejecución despachada, lo que se convierte en un supuesto de probatio diabólica. Ob, cit pág. 488. Y no únicamente los extractos, sino cuantos documentos sean útiles y convenientes para el mejor desarrollo de la ejecución. En este punto, el AAP de valencia de 12 de marzo de 2003.

${ }^{40}$ La creciente morosidad en ciernes..... ob, cit.

${ }^{41} \mathrm{Ob}$, cit, pág. 251. 


\section{EJECUCIONES PARCIALES: EL ÁMBITO DE LA HIPOTECA FLOTANTE}

En todo caso, lo que sí resulta claro es que el legislador quiere imponer un saldo final global, razón por la que demanda una previsión contractual sobre el modo de proceder a su fijación. Busca, en definitiva, la unificación contable para simplificar el proceso hipotecario, especialmente complejo en el supuesto de hipotecas flotantes. De esta premisa, deriva, igualmente, la lectura de que el art. 153 bis LH marca la tendencia a una ejecución única, por el saldo global vencido. Sin embargo, esta regla cuenta con varias excepciones. Las modalidades hipotecarias que aseguran títulos valores permiten varias ejecuciones parciales, y, consiguientemente, la subsistencia de la hipoteca hasta que se agote la responsabilidad hipotecaria. Incluso, la posibilidad de ejecución parcial está prevista en el art. 693 LEC cuando la obligación garantizada ha de pagarse a plazos, siempre que estuviese amparada por la correspondiente estipulación negocial inscrita en el Registro ${ }^{42}$. En este caso, la hipoteca subsiste y merced a la ejecución, se transferirá la finca al comprador con la hipoteca correspondiente a la parte del crédito que no estuviera satisfecha.

Sin embargo, un sector de la doctrina (CARRASCO PERERA y CORDERO LOBATO) considera que los términos ejecución parcial e hipoteca global o flotante son de todo punto incompatibles, pues la subsistencia de gravamen conllevaría resultados absurdos: el adquirente de la finca sería un convidado de piedra ante las nuevas operaciones que podrían suscribir acreedor y deudor, que seguirían aprovechando el gravamen en la parte no agotada por la ejecución, o en caso contrario, obtendría un enriquecimiento injusto, pues habrá descontado el importe del remanente hipotecario al pujar por la finca.

Por su parte, PAZ-ARES, considera que tal solución puede restarle valor a esta modalidad hipotecaria y que podrían encontrarse argumentos a favor de ejecuciones parciales. Partiendo de la premisa básica según la cual lo que se ejecuta es la obligación con el soporte de la garantía, la regla general, afirma, no implica tanto que la hipoteca haya de ejecutarse en su totalidad, sino más bien que el crédito garantido se ejecute de una vez. A su juicio, las normas de las que se infiere la regla general según la cual toda ejecución determina la cancelación del gravamen, se fundan probablemente en la consideración de que la hipoteca asegura una sola obligación, lo que permite establecer una

\footnotetext{
${ }^{42}$ Ahora, tras la Ley 1/2013, de 14 de mayo, de medidas para reforzar la protección de los deudores hipotecarios, reestructuración de la deuda y alquiler social, debe hacerse constar por el Notario en la escritura de constitución.
} 
perfecta correlación entre deuda y garantía. No obstante, esta teoría que era dominante hasta la Ley 41/2007 debe matizarse con la regulación de la hipoteca flotante, cuya característica principal es que asegura diversas obligaciones ${ }^{43}$. Sin perjuicio de que PAZ-ARES cita la hipótesis prevista en el art. 693 de la LEC como la clara excepción a la regla general antedicha, es decir, la que permite la ejecución fraccionada de una deuda, insiste en que del tenor de los arts. 154 y 155 de la LH pueden extraerse una regla propia, perfectamente compatible con la anterior: la de posibilidad de ejecución aislada, pero total respecto de cada uno de los diferentes créditos cubiertos por la garantía, sobreviviendo la hipoteca global por el remanente. Con todo es necesario que se pacte expresamente y se solicite el acceso registral de esta posibilidad de ejecución parcial. Dicho pacto cae dentro del ámbito negocial que se reconoce para establecer la forma de determinación del saldo líquido ${ }^{44}$.

Por su parte, CANLE FERNANDEZ considera que en el estudio de esta materia, el de las ejecuciones parciales en la hipoteca flotante, caben distinguir dos supuestos: aquellos en los que habiendo sido inicialmente constituida la hipoteca flotante a favor de un solo acreedor, concurren con posterioridad una pluralidad de ellos; aquellos otros en los que sin darse dicha pluralidad, el acreedor hipotecario pretenda la ejecución parcial de la hipoteca por las cantidades efectivamente adeudadas, pero conservando su derecho de garantía respecto de las restantes obligaciones susceptibles de aseguramiento.

Para el autor últimamente citado, dentro del primer supuesto, es decir, que hubiese pluralidad de acreedores (originaria o sobrevenidamente) a su vez, conviene distinguir según tengan asignada cada uno de ellos una parte en la responsabilidad hipotecaria máxima o, por el contrario, no exista asignación de cuotas. Si cada uno de ellos tiene asignada en garantía de sus respectivos créditos una parte en la responsabilidad hipotecaria, cualquiera de los acreedores está habilitado para instar la ejecución parcial hasta donde alcance su cuota de participación. Por el contrario, si no existe la anterior distribución, afir-

${ }^{43}$ Una gráfica definición de la figura la encontramos en la Resolución de la DGRN de 25 de abril de 2005; la define como aquella hipoteca que garantiza todas aquellas obligaciones, existentes y futuras, que haya o pudiera haber entre acreedor y deudor, de tal modo que la hipoteca flote sobre ellas para, en el momento en que el acreedor desee ejecutar alguna, algunas o todas las que, siendo vencidas, liquidas y exigibles no hayan sido satisfechas, dejarse caer sobre la obligación u obligaciones incumplidas que el acreedor desee estén cubiertas por la garantía hipotecaria y ejecutar ésta con la preferencia que respecto de otros acreedores deba tener aquél, a consecuencia de la naturaleza del derecho real y de la fecha de inscripción en el Registro.

${ }^{44}$ Paz-Ares, El título de crédito.....ob, cit, págs. 195 y siguientes. 
ma CANLE FERNÁNDEZ, la ejecución parcial no será admisible, pues su ejercicio por uno de ellos determinaría un perjuicio para los demás, que verían reducido el límite máximo de responsabilidad hipotecaria en garantía de sus créditos.

De otro lado, en el caso de que el acreedor hipotecario pretenda la ejecución de la hipoteca por las cantidades efectivamente adeudadas, si bien conservando incólume su derecho de garantía respecto de las restantes obligaciones susceptibles de aseguramiento, sin perjuicio de la reducción del límite máximo garantizado en la cantidad concurrente con la suma obtenida en la ejecución, es perfectamente posible, afirma CANLE FERNANDEZ, la ejecución parcial de la hipoteca flotante por aplicación analógica de la previsión contenida en el art. 693 LEC, o la contemplada en el art. $155 \mathrm{LH}$ respecto de la hipoteca en garantía de títulos a la orden o al portador. No obstante, desde el punto de vista del acreedor hipotecario resulta más prudente pactar en la escritura de constitución del gravamen el vencimiento anticipado de todas y cada una de las obligaciones garantizadas por la hipoteca flotante ante el incumplimiento de cualquiera de ellas, sean éstas de titularidad única de un solo acreedor hipotecario, sean de titularidad de una multiplicidad de ellos ${ }^{45}$.

Al margen de lo anterior, supuesta la posibilidad de ejecutar una hipoteca global a través del procedimiento ejecutivo hipotecario y supuesta igualmente, la posibilidad de ejecuciones parciales en los términos vistos, ni que decir tiene que la necesidad de integrar el título ejecutivo con otros documentos se hace más evidente. En estos casos, asegura PAZ-ARES, el título no expresa la deuda que se trata de reclamar, no tiene autonomía ejecutiva y en consecuencia se hace preciso hacer una recopilación documental para fundamentar la pretensión ejecutiva. La labor se complica toda vez que el art. 153 bis LH no establece cómo se ha de componer el título ejecutivo, ni facilita enumeración documental alguna. Sin embargo, a tenor de lo dispuesto en los arts. 517, 550, 573, 574, 685 LEC y 153 y 153 bis LH, pueden señalarse como documentos que han de acompañar a la demanda ejecutiva los siguientes: el documento constitutivo de la hipoteca, acreditado mediante copia autorizada o certificación registral; el título ejecutivo propiamente dicho en el que consta la existencia de la deuda. Si la relación obligatoria ha sido formalizada mediante escri-

${ }^{45}$ Este pacto conocido en la práctica anglosajona como cross default o cross aceleration agreement, celebrado con amparo en el art. 693.2 LEC, y objeto de la correspondiente inscripción registral, faculta al acreedor o acreedores hipotecarios para proceder a ejecutar por la totalidad de la deuda garantizada, pese a que haya sido objeto de incumplimiento una pequeña parte de la misma. Ob, cit, págs. 345 y 346

(C) UNED. Revista de Derecho UNED, núm. 14, 2014 
tura pública o póliza, habrá de acreditarse mediante copia autorizada ejecutiva, expedida con los requisitos del art. 233 del Reglamento Notarial. Si la existencia de la obligación se constata en documento privado o depende de un pronunciamiento judicial, el título ejecutivo habría de ser judicial. Asimismo, se requerirá el documento del que resulte el saldo final líquido reclamado. Podrá ser la libreta de ejemplares duplicados, o la certificación expedida por el acreedor, siempre que medie el correspondiente convenio. El documento fehaciente del que resulte haberse practicado la liquidación en la forma convenida por las partes; y, por último, el documento que acredite la notificación del deudor y a los fiadores.

\section{EL DOCUMENTO PÚBLICO ELECTRÓNICO}

Tal y como se aventuraba anteriormente, el documento público electrónico es el fiel reflejo de lo desacompasadas que van la legislación notarial y la procesal ${ }^{46}$. De un lado, el avance de las nuevas tecnologías ha supuesto la aparición de nuevos mecanismos documenta-

\footnotetext{
${ }^{46}$ Mira Ros reconoce que los títulos extrajudiciales que llevan aparejada ejecución son esencialmente títulos notariales. Cuando se trata de la ejecución de títulos no jurisdiccionales, el proceso tiene su punto de arranque en un documento cuya regularidad formal escapa entonces al Derecho procesal y convierte la legislación notarial en un mecanismo de integración de la normativa procesal. Sucede, sin embargo, que la conexión entre la legislación notarial y la procesal, actualmente, no está bien establecida. Y si hubiera que señalar un punto de desencuentro, quizás, el más paradigmático, sea, precisamente, el art. 517 LEC, cuando, al enumerar los títulos que llevan aparejada ejecución, formula una remisión del todo inconsecuente, por anacrónica ya, a la legislación notarial. El Derecho Notarial ha evolucionado sensiblemente tras la nueva Ley de Enjuiciamiento Civil. Ha habido una fusión de cuerpos (al quedar integrados los antiguos Agentes de Cambio y Bolsa y Corredores de Comercio Colegiados en un nuevo cuerpo único de Notarios), ha habido un extraordinario avance de las nuevas tecnologías que está condicionando la actividad notarial. Multitud de leyes nuevas, como la legislación contra el fraude fiscal o el blanqueo de capitales, o sobre la firma electrónica, han dado nueva redacción en muchos aspectos al articulado de la vetusta ley del Notariado del año 1862 y sea promulgado una reforma sustancia del Reglamento Notarial que es casi un nuevo Reglamento. Como resultado de todo este movimiento legislativo de reforma se ha producido una modificación de los títulos ejecutivos, pues la pólizas que ahora intervienen los Notarios ya no circulan en original, igual que tampoco existen los asientos del Libro-registro de operaciones ni los certificados con cargo al mismo, contrariamente a la letra de ese art. 517 de la LEC. Igualmente, la fuerza ejecutiva de la primera copia de una escritura pública ya no se corresponde con el nuevo concepto de copia ejecutiva que resulta de la vigente reglamentación notarial. Pero, sobre todo, las nuevas tecnologías en el ámbito de las telecomunicaciones han permitido el desarrollo del denominado documento público electrónico. Con él ha cambiad la fisonomía documental del derecho Notarial. Sin embargo, la incidencia del documento notarial electrónico como título ejecutivo ni siquiera se contempla en la legislación procesal. Los títulos ejecutivos no jurisdiccio-
} 
les a los que alude la legislación notarial; de otro, la legislación procesal no contempla ni por asomo la existencia del denominado documento público electrónico como título ejecutivo, y, en general, se ha ido quedando rezagada respecto de la realidad que imponen los cambios operados en el Derecho Notarial, que sí ha recogido expresamente los avances tecnológicos.

Es de suponer que con el tiempo el documento electrónico asuma la importancia que merece dados los tiempos que vivimos, en los que la informática y los avances tecnológicos se ponen al servicio de la denominada sociedad de la información. Llegado ese día, es posible que los jueces únicamente despachen ejecución con base en copias notariales electrónicas, pues constituyen un medio seguro para evitar los problemas que conlleva para el acreedor la pérdida del título obtenido, seguramente mucho tiempo antes.

No obstante, mientras esto no ocurra, y la legislación procesal sea modificada en el sentido indicado para que las copias electrónicas de documentos puedan tener virtualidad ejecutiva, la copia electrónica no tendrá incidencia en la práctica. Es más una intención que una firme realidad. Con ello, la propia legislación procesal está desaprovechando la ocasión de situarse a la altura de las exigencias que imponen las nuevas medidas legales de impulso a la productividad en la sociedad de la información. Se pretende, en síntesis, la plena interconexión telemática de las Administraciones Públicas, los Juzgados, el Registro, las Notarías y oficinas públicas en general. En este contexto la Ley 11/2007 de 22 de junio, de acceso electrónico de los ciudadanos a los servicios públicos avanza en esta dirección al proclamar el derecho de estos a relacionarse con las Administraciones por vías electrónicas.

Con todo, el llamado documento público electrónico es tan solo una copia o reproducción telemática del documento original elaborado y conservado en papel por el Notario en su archivo; hasta que los avances tecnológicos permitan sustituir ese original en papel por un soporte telemático. Por razones de seguridad, la ley impone que el circuito en el que circula esa copia sea cerrado. Po tanto, la remisión de una copia por vía electrónica exige necesariamente un destinatario que coopere en su recepción y ese destinatario o receptor, a día de hoy, únicamente puede ser otro Notario o funcionario público judicial, registral o administrativo. A los particulares interesados en un documento notarial sólo cabe remitir por vía telemática, todo lo más,

nales: la necesidad de coordinar la legislación procesal con la legislación notarial. En la ejecución civil: problemas actuales, Atelier 2008, págs. 410 y 411.

(C) UNED. Revista de Derecho UNED, núm. 14, 2014 
una copia simple, sin firma digital reconocida, por lo que dichos particulares no podrán ser nunca destinatarios, ni estar en posesión de documentos notariales electrónicos ${ }^{47}$.

Si los avances tecnológicos a los que se alude, han determinado la aparición de nuevos documentos notariales que debidamente dotados de fuerza ejecutiva, podrían servir de fundamento a cualquier ejecución hipotecaria, es indudable que tales avances obligaran igualmente a enfocar desde nuevas perspectivas la publicidad registral. Para ALVAREZ-SALA, la Ley 24/2005 para impulso de la productividad va a significar un cambio profundo del sistema de funcionamiento de Notarías y Registros. Sin embargo, y sin perjuicio de que la digitalización del Registro va a permitir su consulta en cualquier momento ${ }^{48}$ con las ventajas que ello conlleva, hay que atajar sus posibles desventajas. En este sentido, hay que garantizar la inatacabilidad del Registro frente a la piratería informática. Asimismo, hay que favorecer la protección de los datos de carácter personal, de manera que únicamente accedan al Registro aquellos datos que interesen desde el punto de vista de la publicidad registral, es decir, publicitar tan solo la parte que interesa para dar publicidad a la nueva situación jurídica de propiedad derivada de los contratos omitiendo todos los demás.

\section{LA LIMITADA EJECUTORIEDAD DE LA ESCRITURA PÚBLICA}

Según se ha afirmado reiteradamente, el título ejecutivo hipotecario es el título de crédito, dotado de las formalidades procesales adecuadas para desplegar toda su fuerza ejecutiva. Una de esas formalidades, derivada del art. 517 de la LEC es que conste en escritura pública, siempre y cuando conste a su vez la liquidez de la deuda. No se pretende en este punto volver sobre el tema de la liquidez de la obligación, tan solo aludir a lo que algunos autores consideran una clara incoherencia en nuestro sistema y un anacronismo difícil de justificar. En efecto, para GONZALEZ-CUELLAR, la exigencia de liquidez establecida en el título se ha considerado consustancial a la ejecutoriedad del documento notarial por simple inercia y apego a la tradición ${ }^{49}$.

\footnotetext{
${ }^{47}$ Mira Ros, Los títulos ejecutivos no jurisdiccionales...ob, cit, págs. 412 y 413.

${ }^{48}$ Afirma Alvarez-Sala que «el registro va a estar colgado de la red». Nuevas perspectivas de la publicidad registral, Revista El Notario del siglo XXI, enero-febrero de 2012, n. 41.

${ }_{49}$ «En su origen los instrumentos confesionata o guarentigiata, antecedentes de las escrituras públicas ejecutorias, se entendía que llevaban implícito un mandatum de solvendo, que inicialmente se basaba en la pena pecuniaria por el incumplimiento de la obligación que el deudor aceptaba abonar al acreedor. Abandonada tan arcaica
} 
Pero la restricción de la ejecutoriedad de la escritura pública notarial a las obligaciones de dar liquidas o liquidables es discriminatoria porque coloca en mejor situación procesal al proveedor de bienes o servicios que al adquirente de los bienes o servicios, sin razón alguna que lo justifique. No hay razón, sostiene, para que la obligación de pago de un comprador de vivienda en escritura pública pueda ser ejecutada, pero no pueda acudirse directamente a la ejecución forzosa con base simplemente en el título para obtener la entrega del inmueble. En definitiva, GONZALEZ-CUELLAR considera que una reforma semejante a la producida en Alemania, en donde se amplió la ejecutabilidad de la escritura pública a cualquier clase de prestación, sea de dar, hacer o no hacer, sería bienvenida en nuestra legislación ${ }^{50}$. Además, considera que la situación actual coloca en clara desventaja a la escritura pública española en el ámbito de la Unión Europea, en donde trata de asegurarse la libre circulación de resoluciones judiciales y otros títulos de ejecución, pues los títulos notariales alemanes, por ejemplo, serían perfectamente ejecutables en Alemania y España, en tanto que ciertos títulos españoles no serían susceptibles de ejecución ni en uno ni en otro país ${ }^{51}$, al estar condicionados por el presupuesto de la liquidez.

concepción de la posibilidad de ejecutar el documento notarial, el requisito de la liquidez no puede encontrar apoyo en ella. Más relevancia ha tenido históricamente, para la subsistencia del requisito de la liquidez, el brocardo nemo praecisi cogi potest ad factum, el cual, aunque nunca se ha referido específicamente a la ejecución de los títulos notariales, sí ha proporcionado un confuso contexto jurídico-cultural en el que la exigencia de liquidez de la obligación, superado ya para la ejecución de títulos jurisdiccionales, ha subsistido petrificada para los extrajudiciales, como los fósiles de viejos seres marinos que se tuestan al sol en áridas montañas». GonZALEZ-CuELLAR SERRANO, La limitada ejecutoriedad de la escritura pública: incoherencia del sistema. Revista El Notario del siglo XXI, julio-agosto 2011, n. ${ }^{\circ} 38$, pág. 8

${ }^{50}$ En la RFA, la segunda Ley de Reforma de la Normativa sobre Ejecución Forzosa de 17 de diciembre de 1997 ha modificado el número 5 del apartado 1 del parágrafo 794 de la Zivilprozessordnung (ZPO), con el fin de ampliar la ejecución de la escritura pública a cualquier clase de prestación, de dar, hacer o no hacer, cuando sea susceptible de ser regulada contractualmente y excepción hecha de las que afecten a la subsistencia de una relación arrendaticia de vivienda, si el deudor somete la prestación delimitada en el título a ejecución inmediata. Su justificación reside en la salvaguardia de la igualdad de armas entre los contratantes, especialmente en el mercado de la promoción inmobiliaria. Ob, cit, pág. 10

${ }^{51}$ «En la UE trata de asegurarse la libre circulación de resoluciones judiciales y otros títulos de ejecución mediante diversos textos normativos entre los que destaca el Reglamento CE 44/2001, del Consejo, de 22 de diciembre de 2000, relativo a la competencia, el reconocimiento y ejecución de resoluciones judiciales en materia civil y mercantil, el cual contempla los documentos públicos con fuerza ejecutiva en su art. 57.1, en virtud del cual los documentos notariales alemanes que recogen obligaciones de dar cosa específica, hacer o no hacer son ejecutables en Alemania y también en España, mientras que los documentos notariales españoles idénticos no pueden ser ejecutados en España ni tampoco en Alemania, lo que coloca en situación

(C) UNED. Revista de Derecho UNED, núm. 14, 2014 


\section{LA EJECUCIÓN HIPOTECARIA SIN TÍTULO EJECUTIVO}

Tal y como viene afirmándose una y otra vez, el fundamento de todo proceso de ejecución es el título ejecutivo; dicho fundamento se expresa en el aforismo nulla executio sine título. En definitiva, sin título, sencillamente no puede existir proceso de ejecución, pues la presentación formal y el contenido del título son presupuestos esenciales del procedimiento cuya concurrencia debe examinar el tribunal de oficio antes de admitir a trámite la demanda de ejecución.

Ahora bien, la confusión doctrinal existente entre título de crédito y título inscrito ha suscitado la duda de si con base únicamente en la inscripción, cabe acudir al procedimiento ejecutivo. Desde aquí se niega tal posibilidad habida cuenta que sostenemos que el título ejecutivo lo es el de crédito, revestido con las formalidades exigidas en la ley procesal para gozar de fuerza ejecutiva.

El problema, sin embargo, se suscita en torno a aquellos supuestos en que la hipoteca se constituye en garantía de una deuda preexistente o de una deuda futura. Esta deuda asegurada con una hipoteca posterior o anterior válidamente establecida puede no resultar de un documento público, sino de un documento privado. En este punto, sostiene MIRA ROS que no nos hallamos ante una hipótesis de laboratorio, antes al contrario, la hipoteca en garantía de deudas derivadas de documento privado es harto frecuente cuando se trata de macro operaciones financieras formalizadas en el extranjero, a partir de contratos marco entre bancos y empresas multinacionales que imponen a sus sociedades filiales la obligación de constituir hipoteca sobre inmuebles situados en sus respectivos países, en garantía de las obligaciones asumidas por sus sociedades matrices.

Otro supuesto que iría en la misma dirección es el de la hipoteca naval que podrá constituirse, según el art. 3 de su Ley reguladora, por documento privado que firmen los interesados o sus apoderados.

Por último, pueden plantearse igualmente dudas en los casos en que el importe de la responsabilidad hipotecaria afectante a una pluralidad de fincas se distribuye entre ellas mediante documento privado. DIAZ CADORNIGA define la distribución de la responsabilidad hipotecaria como el acto en cuya virtud se procede a la fijación de la parte de crédito de que deba responder cada una de las fincas cuando sean varias las que se hipotequen a la vez en garantía de un solo cré-

de desventaja competitiva al Notariado español, sin causa alguna que lo justifique. Ob, cit págs. 11 y 12 
dito, o cuando la finca hipotecada se divida en dos o más, o se segregue de ella alguna parte. La distribución, así definida está sujeta a la exigencia general de documentación pública, si bien el art. 216 del Reglamento Hipotecario ${ }^{52}$ introduce una excepción, para muchos injustificable ${ }^{53}$, cuando se refiere a la solicitud que los interesados pueden presentar al Registrador acerca de la distribución efectuada.

Por su parte, JIMENEZ PÉREZ acentúa el carácter de negocio jurídico bilateral de la distribución de responsabilidad hipotecaria, tal y como hace la propia Ley Hipotecaria, que en el art. $123^{54}$ enfatiza que voluntariamente lo acordaren el acreedor y el deudor.

La solicitud a que alude el art. 216 del Reglamento Hipotecario no deja de ser un documento privado que presentan los interesados y aunque se firme o ratifique ante el Registrador, o un Notario legitime las firmas, seguirá siendo un documento estrictamente privado y, como tal, sin virtualidad ejecutiva alguna. Sostiene, en este sentido, DE LA PUENTE ALFARO que la instancia privada a que se refiere el art. 216 del Reglamento no tiene otra virtualidad que aclarar o rectificar la previa distribución hipotecaria realizada en documento público siempre que la aclaración o rectificación no sea de tal calibre que exija una nueva declaración de voluntad, en cuyo caso es preciso el otorgamiento de escritura pública o sentencia judicial.

En todos estos casos en que la deuda garantizada con hipoteca no puede ser exigible directamente por vía ejecutiva, al faltar su fundamento esencial, es decir, el título ejecutivo, el acreedor habrá de acudir al juicio pertinente a fin de obtener el pronunciamiento jurisdiccional que confirme la existencia de la deuda garantizada. Será este último, el título que habilite para acudir al juicio ejecutivo donde la traba preconstituida a modo de hipoteca dispensará de tener que de-

${ }^{52}$ Cuando afirma: «...No se inscribirá ninguna hipoteca sobre varias fincas, derechos reales o porciones ideales de unas y otros, afectos a una misma obligación, sin que por convenio entre las partes, o por mandato judicial, en su caso, se determine previamente la cantidad de que cada finca, porción o derecho deba responder. Los interesados podrán acordar la distribución en el mismo título inscribible o en otro documento público, o en solicitud dirigida al registrador firmada o ratificada ante él, o cuyas firmas estén legitimadas. La misma norma se aplicará a las inscripciones de censos y anticresis. Lo dispuesto anteriormente no será de aplicación a las anotaciones preventivas...».

${ }^{53}$ Diaz CADORNiga lo califica de flagrante extralimitación legal, La peligrosa distribución de la responsabilidad hipotecaria en documento privado. www.groups.google. es/group/levante-notarial.

${ }_{54}$ «Si una finca hipotecada se dividiere en dos o más, no se distribuirá entre ellas el crédito hipotecario, sino cuando voluntariamente lo acordaren el acreedor y el deudor. No verificándose esta distribución, podrá repetir el acreedor 
cretar embargo alguno, por ser innecesario y no añadir nada a la traba privilegiada que supone la garantía real ${ }^{55}$.

\section{CARÁCTER EJECUTIVO DEL DOCUMENTO PRIVADO DE MEDIACIÓN}

El Real Decreto- Ley 5/2012, de 5 de marzo, de mediación en asuntos civiles y mercantiles ${ }^{56}$ resulta de aplicación a las mediaciones en asuntos civiles o mercantiles, incluidos los conflictos transfronterizos, siempre que no afecten a derechos y obligaciones que no estén a disposición de las partes en virtud de la legislación aplicable. Traemos a colación esta normativa reciente, pues contempla de forma expresa la ejecución de los acuerdos de mediación, si bien, de forma distinta, afortunadamente, a cómo se recogía en el proyecto inicial. En efecto, en el Proyecto de Ley se establecía expresamente que el acuerdo de mediación tendría plena eficacia ejecutiva y sería título suficiente para poder instar la ejecución forzosa en los términos previstos en la Ley de Enjuiciamiento Civil, siempre que a la demanda ejecutiva se acompañara copia de las actas de la sesión constitutiva y final del procedimiento.

Ante los términos en que se pronunciaba el Proyecto de Ley de Mediación en este punto, se alzaron voces en contra de la referida disposición. Así, TORRES ESCAMEZ ${ }^{57}$ afirmó que con ello se alteraba de una manera muy importante y errónea los principios en que se basa nuestro sistema procesal. En éste, los efectos extraordinarios

${ }^{55}$ Mira Ros, Un nuevo enfoque...., ob, cit, pág. 16.

${ }^{56}$ BOE 6 de marzo de 2012 y corrección de errores de 16 de marzo.

57 Torres Escamez sigue diciendo: «...No parece suficiente para evitar esos inconvenientes la vaga referencia que hace el art. 29 del Proyecto («no podrán ejecutarse los acuerdos cuyo contenido sea contrario a Derecho»), que, además, de ser demasiado abstracta, llevaría, si se interpreta correctamente, a una implicación más profunda de los Tribunales, que es precisamente lo que trata de evitar la mediación. Para decirlo de una manera muy clara y muy simple: el acuerdo no puede ser ejecutivo si no tiene control de legalidad. Si de lo que se trata es de aliviar la sobrecarga de los Tribunales, ese control sólo puede ser notarial.... La correcta interpretación del art. 6.1 de la Directiva Comunitaria 2008/52( «Los Estados miembros garantizaran que las partes, o una de ellas con el consentimiento explícito de las demás, puedan solicitar que se dé carácter ejecutivo al contenido de un acuerdo escrito resultante de una mediación»), sólo puede ser en el sentido de que los Estados miembros que no tengan previsto en su sistema un procedimiento ejecutivo de los acuerdos deberán implantarlo. Pero esto no sucede en aquellos otros que contemplan la homologación judicial o la escritura notarial ejecutiva». Ejecuta como sea (o el carácter ejecutivo del documento privado de mediación). Revista el Notario del siglo XXI, julio-agosto 2011, n. ${ }^{\circ} 38$, págs. 34 y 35 . 
que produce el título ejecutivo tienen su fundamento en lo que se denomina título de calidad: la escritura pública o la sentencia judicial. Pero con el artículo proyectado, aventuraba este autor, se iba a producir una fisura del sistema, pues resultaba directamente ejecutivo el documento privado realizado con intervención del mediador.

De la crítica parece que se hizo eco el legislador, pues en el texto finalmente aprobado y publicado en el $B O E$ se contempla el carácter ejecutivo del acuerdo pero previa su elevación a escritura pública, con lo que se opta por mantener la esencia de nuestro sistema procesal en el que la ejecución se apoya siempre en documentos sometidos a control de legalidad, sea el del juez, sea el del Notario ${ }^{58}$. Concretamente, el Real Decreto-Ley 5/2012 distingue, de un lado, que las partes puedan elevar a escritura pública el acuerdo alcanzado tras un procedimiento de mediación, que será título ejecutivo; de otro, cuando el acuerdo se haya alcanzado en una mediación desarrollada después de iniciarse un proceso judicial, las partes podrán solicitar del Tribunal su homologación conforme lo dispuesto en la LEC. El Auto que apruebe u homologue el acuerdo de mediación es título ejecutivo ${ }^{59}$.

\footnotetext{
${ }^{58}$ Estipula el art. 25 del Real Decreto-Ley, de 5 de marzo, de mediación en asuntos civiles y mercantiles: «1. Las partes podrán elevar a escritura pública el acuerdo alcanzado tras un procedimiento de mediación. El acuerdo de mediación se presentará ante un Notario acompañado de copia de las actas de la sesión constitutiva y final del procedimiento. 2. Para llevar a cabo la elevación a escritura pública del acuerdo de mediación, el Notario verificará el cumplimiento de los requisitos exigidos en este real decreto- ley y que su contenido no es contrario a Derecho....»

${ }^{59}$ Hasta el presente Real Decreto-Ley 5/2012, el legislador distinguía entre títulos ejecutivos judiciales o arbitrales, y títulos ejecutivos no judiciales ni arbitrales. De esta forma, el auto que apruebe u homologue el acuerdo de mediación se habría incluido en el primer grupo, mientras que la escritura pública del acuerdo de mediación se habría incluido en el segundo. El único problema, sostiene MARTín PASTOR, para esta solución habría estado representado por el art. 520 de la LEC, que, al regular la acción ejecutiva basada en títulos no judiciales ni arbitrales, establece la que la única clase de prestación que pueden incorporar estos títulos es la prestación dineraria, mientras que los acuerdos de mediación elevados a escritura pública pueden incluir prestaciones de otra clase. A su juicio, para salvar este escollo se podría haber matizado, tras su correspondiente modificación, que los acuerdos de mediación pudieran incorporar prestaciones tanto dinerarias como de otra índole. Sin embargo, no ha sido esta la opción del legislador que se ha decantado por equiparar o asimilar, a todos los efectos, los diferentes acuerdos de mediación, tanto los aprobados u homologados por el Tribunal como los elevados a escritura pública por el Notario, a los títulos ejecutivos judiciales o arbitrales, con el objeto de potenciar esta forma extrajudicial de solución de controversias. De esta forma, tras el RDL 5/2012 en materia de títulos ejecutivos hay que distinguir entre los títulos judiciales, los arbitrales y los acuerdos de mediación elevados a escritura pública; y los títulos ejecutivos distintos de los anteriores. MARTín PASTOR, La reforma del proceso civil de ejecución por el Real Decreto-Ley 5/2012, Diario La Ley n. ${ }^{\circ}$ 7862, 21 de mayo de 2012.
} 
